\title{
TUTELA PROCESSUAL DO MEIO AMBIENTE NO BRASIL
}

\section{PROCEDURAL PROTECTION OF THE ENVIRONMENT IN BRAZIL}

\author{
${ }^{1}$ Marcelo Antonio Theodoro
}

\section{RESUMO}

O constituinte previu garantias processuais constitucionais para a efetivação dos direitos fundamentais, ao que a doutrina chamou de remédios ou writs constitucionais. Dois deles especialmente interessam à tutela jurisdicional dos direitos fundamentais: A Ação Popular e a Ação Civil Pública. É desses instrumentos de garantia que se tratará no presente ensaio.

Palavras-chave: Meio ambiente; Interesses Difusos e Coletivos; Garantias Constitucionais; writs

\begin{abstract}
The originary constituent safeguards defenses mechanisms for the realization of constitutional rights, the right that, the doctrine called as constitutional writs . Two of then, particularly interesting to save-guard the judicial protection of the fundamental rights: The People's and Public Civil lawsuit. this is evidence of a guarantee that we will establish in this script.
\end{abstract}

Keywords: EnvironmentDiffuse and Collective InterestsConstitution Constitutional Guaranteeswrits

\footnotetext{
${ }^{1}$ Doutor em Direito do Estado pela Universidade Federal do Paraná - UFPR, Curitiba, (Brasil). Professor Associado de Direito Constitucional da Universidade Federal de Mato Grosso UFMT, Cuiabá. E-mail: m.theodoro@ uol.com.br
} 


\section{1- INTRODUÇÃO}

O presente ensaio busca avaliar a contribuição das chamadas "Ações Constitucionais", notadamente a Ação Popular e a Ação Civil Pública como instrumentos de proteção dos Interesses Difusos e Coletivos, especialmente em matéria ambiental, conforme previstos na Constituição Federal de 1988.

Como pressuposto de proteção e tutela de seus direitos, a Constituição de 1988 lançou mão de "remédios constitucionais" que são na realidade instrumentos processuais de rito especial e abreviado, em busca de uma resposta efetiva para a sua concretização.

Entre esses "writs" constitucionais, destacam-se dois deles, que se apresentam como mais adequados como instrumentos processuais de proteção ao meio ambiente: A ação popular e a ação civil pública.

É de lembrar que por tradição a proteção dos interesses difusos e coletivos, não é tema que atrai o legislador processual pátrio, mormente nem o Código de Processo Civil de 1973, tampouco o novel diploma processual que entrou em vigência no dia 18 de março de 2016 trata especificamente dessas tutelas.

Coube, portanto, investigar a partir do texto constitucional diretamente, além e da legislação específica, que compõe o chamado microssistema de processo coletivo, como se dá essa proteção.

Logo no item 2, destacar-se-á a proteção ao meio ambiente ecologicamente equilibrado como direito fundamental. A seguir no item 3. Será apresentada a ação popular ambiental, como instrumento de participação do cidadão na vontade geral, destacando que a constituição para efeitos de proteção ambiental não restringe o conceito de cidadania tão somente ao eleitor; no item seguinte, oportuniza-se a verificação dos principais aspectos da ação civil pública, aplicada à proteção do direito ao meio ambiente e por fim conclui-se pelo reconhecimento da instrumentalidade do nosso sistema, na garantia processual da proteção do direito fundamental ao meio ambiente ecologicamente equilibrado, às presentes e futuras gerações.

Utiliza-se o método dedutivo, e a instrumentalização da pesquisa se dá através da revisão bibliográfica e manejo da jurisprudência nacional. 


\section{DIREITO AO MEIO AMBIENTE ECOLOGICAMENTE EQUILIBRADO COMO DIREITO FUNDAMENTAL}

Uma das razões pela qual Ulysses Guimarães ${ }^{2}$ se referiu ao texto constitucional, então recém aprovado (1988), chamando-o de "constituição cidadã", está justamente no reconhecimento de que o grande avanço desta Constituição em relação às anteriores, estava em reconhecer e proteger os direitos fundamentais do homem e da sociedade como um todo.

Especialmente no que concerne ao direito ao meio ambiente ecologicamente equilibrado, na expressão do artigo 225 da Constituição Brasileira, o seu reconhecimento como direito fundamental, decorre, como lembrado por LEITE e $\mathrm{AYALA}^{3}$, "resultado das transformações ocorridas nas últimas décadas, em relação à proteção e à preservação ambiental, o constituinte brasileiro dedicou um capítulo inteiro ao meio ambiente".

Mesmo não estando expressamente inserido no capítulo da Constituição Brasileira que trata dos direitos e deveres individuais e coletivos, "não é possível afastar o seu conteúdo de direito fundamental ${ }^{4 "}$.

Ainda é de se comentar que não há uma abstração nessa proteção, pois efetivamente se presta à proteção do homem, ainda que através da preservação de seu entorno, vez que não só tutela de interesses difusos, como também pode ser transgeracional, uma vez que se dirige inclusive às futuras gerações de seres humanos..

Os direitos de solidariedade e fraternidade, desprendem-se da figura do homem-indivíduo para destinar-se a proteção dos grupos humanos (família, nação, povo) e consequentemente pode-se dizer que atende a proteção de titularidade difusa ou coletiva. Além do meio ambiente poder-se-ia incluir: o direito à paz, à autodeterminação dos povos, ao desenvolvimento, ao meio ambiente, ao consumidor, ao patrimônio histórico e cultural ${ }^{5}$.

\footnotetext{
${ }^{2}$ Ulysses Guimarães, foi o Presidente da Assembleia Nacional Constituinte de 1987, que culminou com a edição da Constituição da República Federativa do Brasil em 05 de outubro de 1988.

${ }^{3}$ LEITE, José Rubens Morato e AYALA, Patryck de Araújo. Dano Ambiental. Do individual ao coletivo extrapatrimonial. Teoria e Prática. 6. ed. São Paulo: Ed. Revista dos Tribunais, 2014, p. 90.

${ }^{4}$ Idem, p. 92.

${ }^{5}$ THEODORO, Marcelo Antonio. Direitos Fundamentais e sua Concretizacão. Curitiba: Juruá, 2002, p. 17.
} 
Alguns exemplos de dispositivos constitucionais que tratam diretamente da proteção ambiental são aqueles previstos nos seguintes artigos, , $5^{\circ}$, LXXIII (legitimidade do cidadão para propor ação popular para evitar lesão ao meio ambiente); 20, II (terras devolutas da União, indispensáveis à preservação ambiental), 21, d (responsabilidade civil absoluta do Estado por danos nucleares); 23, VI (competência comum dos entes federativos para proteção do meio ambiente); 24, VIII (competência concorrente dos entes federativos para legislar sobre responsabilidade civil e criminal decorrente de lesão ao meio ambiente) 129, III (legitimidade do Ministério Público para promoção de Ação Civil Pública em defesa do Meio Ambiente, não excludente de outros legitimados - 129 parágrafo único), 170, VI (princípio da ordem econômica, defesa do meio ambiente), 186, II (requisito da função social da propriedade preservação do meio ambiente), 225 (donde se expressa o princípio fundamental de proteção ao meio ambiente ecologicamente equilibrado); 231 (proteção de direito dos indígenas).

Como foi dito, expressamente a Constituição Federal brasileira, protege o direito ao meio ambiente em diversos dispositivos, mas o que chama atenção por tratar diretamente dessa proteção é o dispositivo constante no "caput" do art. $225^{6}$.

Em razão dessa expressa proteção ao meio ambiente, a legislação infraconstitucional brasileira foi se adequando também para instrumentalizar essa tutela.

Vários mecanismos fiscais, administrativos, de fomento e investimentos foram tecidos pelo legislador, para incentivar, policiar e regular a proteção ambiental.

Todavia muitas vezes a atuação estritamente estatal não é suficiente para garantir a efetividade das previsões materiais do constituinte e do legislador ordinário.

Paulo Afonso Leme Machado ${ }^{7}$, afirma que há um direito fundamental ao processo judicial ambiental, e chega mesmo a asseverar que "Se não houvesse direito ao processo judicial ambiental, o art. 225 da CF ficaria morto, ou restaria uma ideia digna, mas sem concretude".

\footnotetext{
${ }^{6}$ Art. 225 CF/88: "Todos têm direito ao meio ambiente ecologicamente equilibrado, bem de uso comum do povo e essencial à sadia qualidade de vida, impondo-se ao Poder Público e à coletividade o dever de defendê-lo e preservá-lo para as presentes e futuras gerações".

${ }^{7}$ MACHADO, Paulo Afonso Leme. Direito Ambiental Brasileiro. 12 $2^{\mathrm{a}}$ Ed. São Paulo, Malheiros: 2004, pg. 116.
} 
Diante desta tendência reconhecida, é preciso dimensionar, que espécie de tutela processual ambiental se deseja, ou melhor, se apresenta como capaz de dar efetividade à proteção ambiental.

Neste curso, não se pode esquecer da lição de Bryan Garth e Mauro Cappelletti ${ }^{8}$ no célebre “Acesso à Justiça”, resultado do famoso Projeto Florença.

Os autores problematizaram os resultados de um processo calcado na experiência individualista e seus mecanismos convencionais, cujos procedimentos não atendem a expectativa de concretude da prestação jurisdicional justa, mas quando muito, do mero formalismo da atuação jurisdicional do Estado.

Desta forma, segundo os autores, há necessidade de novos mecanismos procedimentais que tornem esses direitos exequíveis .

Os autores identificam vantagens que podem ser obtidas ao se implementar tais mecanismos diferenciados dos tradicionais, como por exemplo:

a) a exploração de uma ampla variedade de reformas de forma a adaptar o dinamismo da sociedade à possibilidade de busca de suas soluções que podem não vir do direito como instituição do Estado simplesmente; b) adequação das normas processuais aos tipos de litígios, de modo a superar as complexidades inerentes a complexidade de cada caso; c) levar em consideração as partes no processo, diante das suas peculiaridades e potencialidades de resolução dos conflitos por diferentes focos, como a barganha, experiência e outros fatores.

Finalmente ressaltam os autores, deve-se levar em conta também que o resultado de uma demanda de interesse difuso possui repercussões individuais e coletivas. Assim, há necessidade de separar as duas dimensões tendo em vista as diferentes implicações.

Resumindo, os autores que o acesso à justiça deve levar em conta todos os fatores mencionado, demonstrando pois a necessidade desse novo enfoque para a realidade em que vivemos .

Esta reflexão importante, permite desenvolver uma análise pontual, acerca do instituto do ônus da prova, e de sua releitura a partir da perspectiva da proteção ambiental, perpassando pelo princípio da precaução.

\footnotetext{
${ }^{8}$ CAPPELLETTI, Mauro e GARTH, Bryant. Acesso à justiça . 1a. Ed. Reimpressão 2002. Tradução de Ellen Gracie Northfleet. Porto Alegre: Editora Sérgio Antônio Fabris, 1988.
} 
Neste ponto, entre o reconhecimento de que a constituição brasileira preconiza um sistema "aberto" e "pluralista", e ainda, que o processo, visto pelo prisma da efetividade da prestação jurisdicional, a rediscussão dos procedimentos aplicados no processo ambiental, ganha fôlego.

E essa rediscussão, deve partir dos princípios que informam o chamado "Estado de Direito Ambiental”*, notadamente o princípio da precaução, e a consequente defesa, de uma mudança de perspectiva, ou seja, redimensionamento do instituto processual do ônus da prova.

Naturalmente o objetivo deste redimensionamento é a busca da "tutela jurisdicional, adequada e justa", para alcançar a efetividade da proteção ao direito ao meio ambiente ecologicamente equilibrado.

\section{A AÇÃO POPULAR}

Expressamente na Constituição brasileira de 1988, foi incluída a Ação Popular como forma direta de controle jurisdicional do patrimônio público, da moralidade administrativa e como inovação da proteção ao meio ambiente.

A ação popular é um mecanismo de participação direta do cidadão na vontade geral. Está entre as previsões do exercício direto da soberania popular, ao lado do plebiscito, referendo e iniciativa popular, apresentados no art. 14 da Constituição Federal, mas também dos demais instrumentos que compõe, o chamado status activus civitatis (ativo), no qual o cidadão recebe competências para participar do Estado, com o fim especial de formar a vontade estatal, apresentado por Jellinek ${ }^{9}$, que englobam ainda as audiências públicas, participações em conselhos populares e sindicatos, além de associações classistas. Chamado também de direito de participação, ou democracia participativa.

\footnotetext{
${ }^{9}$ JELLINEK, George. Teoria general del Estado. Trad. Por Fernando de los Rios. 2 ed. Buenos Aires: Editorial Albatroz, 1974, págs. 313 e ss.
} 
A Ação Popular, na forma prevista no texto constitucional, legitima o cidadão para intentá-la. Todavia é na Lei 4717 de 29/06/65: que se define que para efeitos de aplicação dessa Lei o cidadão há que ser eleitor ${ }^{10}$.

Surgem algumas críticas em relação a essa exigência, entre outros Paulo Affonso Leme Machado, segundo o qual a lei não pode restringir um conceito amplo como o de cidadania, mormente a opção de inclusão desse termo na Constituição nenhuma referência faz a necessidade da habilitação eleitoral ativa.

"Ser cidadão já não é só ser eleitor ou poder ser eleito para cargos ou funções eletivos. É mais: é entre outros direitos, poder integrar órgãos públicos como o Conselho da República(art. 89 VII) ou falar perante as Comissões do Congresso Nacional (art. $58 \S 2^{\circ}$ ) onde não se exigirá a apresentação do título de eleitor para o exercício da cidadania" ${ }^{11}$.

Para Machado, "não é nenhum excesso entender que todos os habitantes do País, brasileiros ou estrangeiros (art. $5^{\circ}$, caput) estão habilitados a utilizar a 'ação popular' ambiental ${ }^{12,}$

Contrapondo-se a essa posição está José da Silva Pacheco, para quem a cidadania na Constituição Federal de 1988 confunde-se com a nacionalidade e portanto só os brasileiros natos e naturalizados poderiam interpor a Ação Popular.

"Portanto, quando a Constituição, no art. 5, LXXIII, alude a cidadão, não se dirige a qualquer pessoa residente no País, tampouco ao nacional no gozo dos direitos políticos (art. 14 da CF), mas ao nacional nato ou naturalizado (art. 12) ${ }^{13}$.

O mesmo autor afirma ainda que, "perdem o direito a propor a ação popular: a) os que perderam a nacionalidade e, deste modo, deixaram de ser cidadãos do Brasil; b) os que perderam os direitos políticos e, não obstante continuem com a nacionalidade brasileira, não podem por si, praticar, temporária ou definitivamente, direitos públicos subjetivos" $" 14$.

Conforme noticiado por Celso Fiorillo ${ }^{15}$, o Superior Tribunal de Justiça vem afastando o conceito restritivo da Lei $4.717 / 65$, ao entender que qualquer cidadão

\footnotetext{
${ }^{10}$ Lei $4717 / 65$, Art. $1^{\circ}, \S 3^{\circ}$ : “A prova da cidadania, para ingresso em juízo, será feita com o título eleitoral ou com documento que a ele corresponda".

11 "MACHADO, Paulo Afonso Lemes, op. cit. p. 118.

${ }^{12}$ Idem, p. 118.

${ }^{13}$ PACHECO, José da Silva. Ações Constitucionais Típicas. 4ª Ed. São Paulo: RT, 2002. p. 564

${ }^{14}$ Idem

${ }^{15}$ FIORILLO, Celso Antonio Pacheco. Curso de Direito Ambiental Brasileiro, 16 a ed. São Paulo: Saraiva, 2015, p. 485;
} 
incluindo os brasileiros e estrangeiros residentes no País, podem propor ação popular ambiental.

Por outro turno, também se discute, agora num prisma positivo, se o cidadão eleitor menor de 18 anos e maior de 16 anos poderia ser autor da ação popular.

Nelson Nery Junior e Rosa Maria de Andrade Nery afirmam que "o eleitor com dezesseis anos é parte legítima para propor ação popular, estando capacitado para o exercício desse poder que decorre da sua condição política de eleitor ${ }^{16 "}$

Defende-se no presente trabalho a Ação Popular como instrumento de garantia constitucional e, portanto, devendo ser interpretado da maneira mais ampla possível tanto no que concerne à sua legitimidade ativa - daí considerar cidadão todo aquele sujeito de direitos e deveres no Estado.

Quanto a legitimação especial, especial aos eleitores maiores de 16 anos, está atrelada na mesmo diapasão do conceito amplo de cidadania, merecendo guarida também esse entendimento.

De qualquer forma, a Ação Popular deve ser intentada por meio de advogado regularmente inscrito na $\mathrm{OAB}$, posto que a Lei não empresta capacidade postulatória ao cidadão.

Por outro lado, é também a Ação Popular uma ação de cunho altruísta, posto que nenhuma vantagem de ordem pessoal será buscada pelo autor da Ação.

Ao contrário, caso se demonstre processualmente a existência de má-fé por parte do autor, este arcará com as custas processuais e honorários advocatícios.

A dúvida então seria, de qual o estímulo para que alguém intente uma Ação Popular?

A resposta só pode ser encontrada no aspecto subjetivo, no qual se busca despertar o sentimento de cidadania, latente em cada indivíduo preocupado com as atividades públicas de seus representantes, e também especificamente na linha deste trabalho, preocupado em garantir para si, para os outros e mesmo para as futuras gerações um meio ambiente equilibrado e ecologicamente sustentável.

${ }^{16}$ NERY JUNIOR, Nelson e NERY, Rosa Maria de Andrade Nery. Código de Processo Civil Comentado. $10^{\mathrm{a}}$ ed. São Paulo: RT, 2007, pág. 348.. 
A legitimação passiva da Ação Popular envolve no que tange ao controle da moralidade administrativa e defesa do patrimônio público, os agentes públicos e as pessoas jurídicas de direito público, estas últimas curiosamente podem ser réus e oportunamente beneficiados pela Ação Popular, inclusive não havendo obrigatoriedade de contestar a Ação, caso seu objeto se demonstre de interesse público ${ }^{17}$. Os particulares podem ser alcançados pela Ação Popular, desde que contratem ou se beneficiem ilicitamente da administração pública, lesando o patrimônio público ${ }^{18}$.

Os exemplos clássicos deste posicionamento são os casos de corrupção ativa, benefícios em superfaturamento, advocacia administrativa e outras situações que transcendem inclusive a esfera da responsabilidade civil e respingam na esfera criminal.

Especificamente em matéria ambiental a Ação Popular ganha contornos específicos, a ponto de alguns autores tratarem de uma "Ação Popular Ambiental”.

Neste sentido a Ação Popular se volta para a proteção do patrimônio ambiental, evitando as diversas situações materiais de agressão ao meio ambiente.

Por objetivos metodológicos a presente pesquisa não se debruçará nas inúmeras hipóteses em que caberia a Ação Popular Ambiental, todavia não se olvida seu caráter preventivo e repreensivo.

Ou seja, a Ação Popular pode ser movida como meio cautelar impeditivo da degradação do meio ambiente. Nesse caso é admitido inclusive o pedido de liminar ${ }^{19}$ ou cabível a tutela antecipada, conforme o caso concreto.

A Ação Popular pode ter o objetivo da responsabilização civil do agressor mediante indenização por danos materiais e eventualmente danos morais coletivos, e a direta reparação do dano quando isto for possível, tudo sem prejuízo da atuação administrativa do Estado, através das multas e outras sanções.

A Ação Popular não admite acordos ou desistência imotivada, sendo neste último caso, facultado ao Ministério Público prosseguir como autor da ação em caráter subsidiário $^{20}$.

\footnotetext{
${ }^{17}$ Lei 4.717/65- Art. $6^{\circ}$ “ (....) $\S 3^{\circ}$ A pessoas jurídica de direito público ou de direito privado, cujo ato seja objeto de impugnação, poderá abster-se de contestar o pedido, ou poderá atuar ao lado do autor, desde que isso se afigure útil ao interesse público, a juízo do respectivo representante legal ou dirigente". ${ }^{18}$ Lei 4.717/65 "Art. $6^{\circ} \mathrm{A}$ ação será proposta contra as pessoas públicas ou privadas e as entidades referidas no art. $1^{\circ}$, contra as autoridades, funcionários ou administradores que houverem autorizado, aprovado, ratificado ou praticado o ato impugnado, ou que, por omissas, tiverem dado oportunidade à lesão, e contra os beneficiários diretos do mesmo".

19 Art. $5^{\circ}, \S 4^{\circ}$ da Lei $4.717 / 65$
} 
O Ministério Público atuará também como "custus leges" ou seja o fiscal da $1 \mathrm{ei}^{21}$.

As custas processuais e honorários, como foi dito, só caberão em caso de comprovada má-fé do autor da ação ${ }^{22}$.

\section{A AÇÃO CIVIL PÚBLICA}

Prevista na Lei 7347/85, e com passagem constitucional no art. 129 III, a Ação Civil Pública legitima ao Ministério Público e à sociedade civil organizada por meio de associações, intentá-la para a defesa dos interesses difusos, que estão diretamente ligados à implementação dos direitos sociais ${ }^{23}$.

Antes da entrada em vigor da Lei da Ação Civil Pública eram poucos os mecanismos legais para que os interesses difusos e coletivos fossem amplamente tratados, a despeito de a Ação Popular, dentro dos limites estabelecidos pela Lei 4.717 de 29 de junho de 1965 referir-se à proteção do patrimônio ambiental ${ }^{24}$, e o próprio Mandado de Segurança, aceito então, exclusivamente na modalidade individual.

Conforme relato de ÉDIS MILARÉ ${ }^{25}$, especialista em direito ambiental, dois fatos ilustram bem a importância e a eficiência da Ação Civil Pública:

O primeiro deles ocorrido no Rio Grande do Sul em 1984 e, portanto, antes da entrada em vigor da Lei de Ação Civil Pública, quando foi detectado que a safra de morangos gaúcha estava contaminada com excesso de agrotóxicos, colocando em risco a saúde da população consumidora. O governador resolveu não embargar a comercialização temendo as ações indenizatórias dos produtores, cabendo a cada consumidor que se sentisse lesado, propor isoladamente seu pleito.

${ }^{20}$ Lei 4.717/65 Art. $9^{\circ}$ "Se o autor desistir da ação ou der motiva à absolvição da instância, serão publicados editais nos prazos e condições previstos no art. $7^{\circ}$, inciso II, ficando assegurado a qualquer cidadão, bem como ao representante do Ministério Público, dentro do prazo de 90 (noventa) dias da última publicação feita, promover o prosseguimento da ação".

${ }^{21}$ Art. $7^{\circ}$, I, a da Lei $4.717 / 65$

${ }^{22}$ Art. $5^{\circ}$, LXXIII da Constituição Federal de 1988.

${ }^{23}$ KRELL, Andreas. Direitos sociais e o controle judicial no Brasil e na Alemanha. Porto Alegre: Sérgio Antonio Fabris Editor, 2002, p. 104.

${ }^{24}$ FERREIRA, Helini Sivini. Os instrumentos jurisdicionais Ambientais na Constituição Brasileira. In Direito Constitucional Ambiental Brasileiro. CANOTILHO, José Joaquim e LEITE, José Rubens Morato, Organizadores. $2^{\mathrm{a}}$ Ed. São Paulo: Saraiva, 2008, p. 323.

${ }^{25}$ MILARÉ, Edis. AÇÃO civil pública completa 20 anos. In RT Informa n 37 maio/junho 2005. Revista dos Tribunais, 2005, p. 04. 
No ano seguinte, já sob a vigência da lei, o leite em pó importado pelo Brasil, junto à Ucrânia, estava sob suspeita, após o desastre nuclear de Chernobyl naquele país, então pertencente à extinta União Soviética. Imediatamente o Ministério público intentou uma Ação Civil Pública e obteve a suspensão do comércio dos lotes importados do leite sob suspeita, além de barrar a importação do produto.

Segundo LUIS ROBERTO BARROSO ${ }^{26}$, após a promulgação da Constituição de 1988, houve uma recepção qualificada da ação civil pública, uma vez que passou a ser função institucional do Ministério Público “ promover o inquérito civil e a ação civil pública para a proteção do patrimônio público e social, do meio ambiente e de outros interesses difusos e coletivos" 27 .

Por outro lado, a Constituição de 1988 deixa claro que "a legitimação do Ministério Público para as ações civis previstas neste artigo (129) não impede a de terceiros, nas mesmas hipóteses, segundo o disposto nesta Constituição e na lei" ${ }^{28}$.

A legitimação ativa da Ação Civil Pública ${ }^{29}$, bastante ampliada a partir do texto constitucional, inclui recentemente através da Lei 11.448/2007 a Defensoria Pública no rol dos legitimados, ao lado do Ministério Público, a União, Estados, Municípios e Distrito Federal, além das autarquias, empresas públicas, sociedades de economia mista, assim como as Associações que estejam constituídas há pelo menos um ano e incluam entre suas finalidades a proteção de interesses difusos, e nesse caso, a proteção ao meio ambiente.

Ainda que houvesse sido questionada pelo Ministério Público, a legitimidade da atuação da Defensoria Pública foi reconhecida pelo Supremo Tribunal Federal em sede de repercussão geral no RE $733.433^{30}$.

Especificamente em matéria ambiental a legitimação das Associações ganha importância dentre o extenso rol dos legitimados.

\footnotetext{
26 BARROSO, Luís Roberto. O direito constitucional e a efetividade de suas normas. $5^{\mathrm{a}}$ ed. Rio de Janeiro: Renovar, 2001, p. 297.

${ }^{27}$ Cf. art. 129, III da Constituição Federal.

28 art. 129 , parágrafo $1^{\circ}$ da Constituição Federal.

${ }^{29}$ Lei $7.347 / 85$, art. $5^{\circ}$ e Lei 8.078/90, art. 82

${ }^{30}$ A Defensoria Pública tem legitimidade para a propositura de ação civil pública em ordem a promover a tutela judicial de direitos difusos e coletivos de que sejam titulares, em tese, pessoas necessitadas." Com esse entendimento, o Plenário do Supremo Tribunal Federal (STF), por unanimidade dos votos, negou provimento ao Recurso Extraordinário (RE) 733433.

(in: http://www.stf.jus.br/portal/cms/verNoticiaDetalhe.asp?idConteudo=303258, acesso em 29 de março de 2016).
} 
No Brasil nos últimos anos, a mídia nominou as Associações que militam em interesses específicos pela sigla ONG, ou seja, Organização Não Governamental.

A despeito da imprecisão que acompanha esse "apelido" uma vez que pode justamente confundir seu âmbito de atuação como paralelo das "organizações governamentais", as ONGs de proteção ao meio ambiente conquistaram seu espaço principalmente pelas campanhas públicas acompanhadas de protestos, alguns criativos, mas também de muita pesquisa, disponibilização de dados e denúncias através da mídia, das agressões cometidas contra o meio ambiente.

As ONGs exercem um papel fundamental na educação ambiental. Muitas vezes recebem recursos privados e principalmente públicos para garantir sua atuação e não raras vezes são criticadas por isso.

As ONGs na área ambiental atuam finalmente também como legitimadas processuais da Ação Civil Pública. Sua tarefa se assemelha aquela do cidadão na Ação Popular, qual seja, proteger de forma altruísta um interesse que não é particular, mas coletivo, difuso, transgeracional.

O Ministério Público, como dito, expressamente é legitimado, mas nos casos em que não atua como titular da ação, podendo atuar como listiconsorte ou ainda ser chamado a participar como "custus leges 31 ".

O cidadão embora não possa atuar diretamente como autor da Ação Civil Pública pode provocar a atuação do Ministério Público, quando tiver conhecimento de lesão ou ameaça ao meio ambiente ecologicamente equilibrado, passando então a ser um dever a atuação do Ministério Público.

A competência para a Ação Civil Pública é portanto, concorrente e disjuntiva, vez que todos os legitimados estão aptos a tutelar os interesses metaindividuais, sem a necessidade da autorização dos demais, ou ainda sem a obrigatoriedade de fazê-lo conjuntamente, embora isso seja possível ${ }^{32}$.

\section{LEGITIMADOS PASSIVOS}

${ }^{31}$ Lei $7.347 / 85$, arts $5^{\circ} \S 1^{\circ}, 6^{\circ}$ e $7^{\circ}$.

${ }^{32}$ LEITE, José Rubens Morato e AYALA, Patryck Araújo, op cit. p. 244. 
Os legitimados passivos em Ação Civil Pública Ambiental são aqueles que causaram lesão ou ameaçam causar, ao meio ambiente ecologicamente equilibrado. Amplo dessa maneira, compreende pessoas naturais, jurídicas de direito público ou $\operatorname{privado}^{33}$

Desta forma, a Ação Civil Pública demonstra-se mais ampla tanto na legitimação ativa, quanto na legitimação passiva, considerada pro excelência o principal instrumento de proteção judicial ao meio ambiente ecologicamente equilibrado.

\section{INQUÉRITO CIVIL}

Não se pode esquecer, que a ação civil pública, pode vir precedida, ou mesmo vir a abrir espaço, para o inquérito civil, sempre presidido pelo Ministério Público, e que será um efetivo instrumento para aferir os elementos necessários para a conclusão in casu a partir de um juízo de ponderação entre os direitos fundamentais colidentes.

Portanto a competência para presidir o Inquérito Civil é exclusiva na forma do art. $8^{\circ}, \S 1^{\circ}$ da Lei 7.347/85 e Art. 129, III da Constituição Federal.

O Inquérito civil pode ser preparatório ou incidental, e requerido por qualquer dos legitimados ${ }^{34}$.

Seu principal objetivo é a dilação probatória, para evitar que a Ação se inicie mal instruída, ou mesmo para se concluir que não há infração a ser apurada.

Pode esse inquérito se valer desde um laudo pericial, quando por visitas "in locu", inspeções, levantamento de documentação, rastreamento de recursos aplicados, ou não aplicados, e mesmo subsídios de ações ou inquéritos criminais.

O caráter inquisitório do Inquérito Civil permite a produção das provas independentemente do contraditório e da ampla defesa, guardados para o processo em si. A justificativa é que nessa fase não há sanção ao investigado ${ }^{35}$.

No caso de não encontrar fundamento para a propositura da ação civil pública, o promotor de maneira fundamentada, poderá promover o arquivamento do inquérito.

\footnotetext{
${ }^{33}$ É legitimada para figurar no pólo passivo da ação civil pública ou da ação coletiva toda pessoa física ou jurídica, de direito público ou privado, ou seja, o causador do dano ao meio ambiente, ao consumidor, ..., ou qualquer outro interesse difuso ou coletivo". SIRVINSKAS, Luís Paulo. Manual de Direito

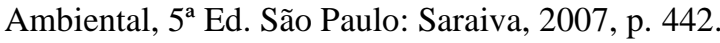

${ }^{34}$ Art. $8^{\circ}$ § $1^{\circ}$ da Lei 7.347/85.

${ }^{35}$ FERREIRA, Heline Sivini, op.cit. p. 330.
} 
Mas nessa hipótese, deverá submeter seu parecer ao Conselho Superior do Ministério público que homologará o arquivamento ou determinará a rejeição e consequente prosseguimento em sede de ação civil ${ }^{36}$.

\section{OBJETO}

A Lei 7.347/85 assevera em seu art. $3^{\circ}$ que a "ação civil poderá ter por objeto a condenação em dinheiro ou o cumprimento da obrigação de fazer ou não fazer".

O objeto da Ação Civil Pública é amplo, além do aludido é a proteção do patrimônio público, meio ambiente, mas amplia-se consideravelmente ao expressar a proteção dos interesses difusos e coletivos .

LEITE e AYALA destacam, que o sistema da Ação Civil Pública "não restringiu o objeto da ação ao aspecto pecuniário, mas acrescentou expressamente a possibilidade de fazer ou não fazer" .

Isso atende principalmente o escopo da judicialização do direito à proteção ambiental, que encerra a busca do restabelecimento do status quo ante, sempre que possível, sem embargo da indenização.

Prosseguem os autores, no sentido de que, "acertou o legislador ao instituir este duplo objetivo, posto que o dano ambiental exige, além da compensação financeira ecológica (...) um mecanismo que cesse a atividade poluente e/ou recupere a lesão ambiental".

Os efeitos da Ação Civil Pública, da mesma maneira que ocorre com a Ação Popular são variados, mas com algumas especificidades.

A Ação Civil Pública pode ser intentada para evitar a lesão ao direito patrimonial protegido, incluindo aí o patrimônio ambiental. Ex. Ação Civil Pública para impedir a construção de uma rodovia em área de Preservação Permanente.

Nessa hipótese também cabe a tutela antecipada, ou mesmo o pedido liminar.

Também o aspecto repressivo é inerente à Ação Civil Pública. A reparação do dano civil, os pedidos de indenização, são efeitos práticos da Ação Civil Pública.

${ }^{36}$ Idem, p. 331. 
Havendo condenação em dinheiro, a indenização será revertida ao Fundo de Defesa dos Interesses Difusos ${ }^{37}$, que permitirá a sua utilização em defesa de vários interesses entre os quais a reparação de danos causados ao meio ambiente.

Quanto à coisa julgada, a Ação Civil Pública produzirá efeitos “erga omnes”, limitando-se à competência territorial do órgão julgador e exceto nos casos em que o pedido for julgado improcedente por insuficiência de provas. Deste modo o art. 16, da Lei 7.347/85 autoriza que qualquer dos legitimados proponha novamente a Ação Civil com os novos fundamentos e provas que tiver.

\section{TERMO DE AJUSTE DE CONDUTA}

O Termo de Ajustamento de Conduta (TAC), além de importantíssimo instrumento de tutela do meio ambiente, é correntemente utilizado para a composição de conflitos na área ambiental.

Carvalho Filho, conceitua o Termos de Ajustamento de Conduta como sendo "o ato jurídico pelo qual a pessoa, reconhecendo implicitamente que sua conduta ofende interesse difuso ou coletivo, assume o compromisso de eliminar a ofensa através da adequação de seu comportamento à exigências legais"38.

Embora o princípio altruísta dessa modalidade de ação constitucional possa levar ao entendimento de que não se concebe acordo, pois se dispõe de interesse alheio, ou seja público, a Lei 7347/85 prevê a possibilidade da celebração de ajuste de conduta, restrita a transação aos legitimados que se constituam órgãos públicos, além do próprio Ministério Público ${ }^{39}$.

Este tema, acerca da disponibilidade em matéria de interesse transindividuais, já foi enfrentado por diversos autores e pela jurisprudência ${ }^{40}$.

Esta previsão legal se encontra no art. $5^{\circ}, \S 6^{\circ}$ da Lei 7347/85, verbis "Art. $5^{\circ}$ : "Têm legitimidade para propor a ação principal e a ação cautelar: I - o Ministério

\footnotetext{
${ }^{37}$ O Fundo de Defesa dos Interesses Difusos foi criado pela Lei no 9.008 de 21 de março de 2005.

${ }^{38}$ CARVAlHO FILHO, José dos Santos. Ação Civil Pública: Comentários por artigo, 3. Ed. Rio de Janeiro: Lumen Juris, 2001, p. 4.

${ }^{39}$ SIRVINSKAS, Luís Paulo. op. cit. p. 446.

40 Recurso Extraordinário no 253-885-0/MG, Rel. Min. Ellen Gracie, Publicado no DJ 21.06.02. www.stf.jus.br, acesso em 29/03/2016.
} 
Público (...)" $6^{\circ}$ Os órgãos públicos legitimados poderão tomar dos interessados compromisso de ajustamento de sua conduta às exigências legais, mediante cominações, que terá eficácia de título executivo extrajudicial."

Édis Milaré ${ }^{41}$, citado por LEITE e AYALA, aponta, como síntese, os requisitos de validade da homologação do ajuste: 1. necessidade de integral reparação do dano, em razão da natureza indisponível do direito violado; a esfera passível de ajuste fica circunscrita à forma de cumprimento da obrigação pelo responsável, isto é, ao modo, tempo, lugar e outros aspectos pertinentes; 2. Indispensabilidade de cabal esclarecimento dos fatos, de modo a ser possível a identificação das obrigações a serem estipuladas, já que desfrutará de eficácia de título executivo judicial; 3. Obrigatoriedade da estipulação de cominações para a hipótese de inadimplemento; 4. Anuência do Ministério Público quando não seja autor".

O cumprimento destas estipulações pelo autor acarreta o eventual interesse na demanda.

Já se todos os elementos do interesse não forem abrangidos, persiste a possiblidade de ajuizar ação civil pública.

Esse compromisso uma vez firmado, constitui-se em título executivo extrajudicial, e uma vez devidamente cumprido extingue-se o interesse no litígio.

\section{CONCLUSÃO}

O constituinte amparou de forma concreta a proteção do meio ambiente e de outros interesses difusos e coletivos através de ações constitucionais que permitem maior celeridade e que ampliam o acesso dos cidadãos a esse controle.

Destacam-se as retroanalisadas ação popular e ação civil pública, pois o acesso do cidadão e da sociedade civil aos meios de provocação jurisdicional, diminuem a sensação de impotência muitas vezes presentes em grandes ou pequenos desastres ambientais, todos eles de responsabilidade do homem, travestido ora como governo, ora como pessoa jurídica, ou pessoalmente.

\footnotetext{
${ }^{41}$ MILARÉ, Édis. Tutela jurídico-civil do meio ambiente. Apud, LEITE, José Rubens Morato e AYALA, Patryck Araújo, 263,
} 
A despeito da legislação punitiva, seja de ordem criminal, seja de ordem administrativa, a responsabilização civil, através de meios processuais céleres, pode, em tempos de exacerbado capitalismo, exercerem o tão buscado caráter inibitório e educativo, que em muitos casos somente o "bolso" consegue sentir.

Por outro turno, a reparação civil também pode minimizar danos, que se, reversíveis, terão o condão de reverter ao "status quo ante", situações que pareciam a primeira vista definitivas.

Méritos por exemplo para instrumentos tais como o " termo de ajustamento de conduta", e mesmo a medidas restaurativas, mormente encaminhadas como "obrigações de fazer", impostas em inúmeros precedentes judiciais, e que paulatinamente vem sendo postas em execução.

O que pode constituir em uma solução moderna e racional, para um problema que, a princípio se apresenta como irreversível, mas que pode ser amenizado de alguma maneira, pelos instrumentos disponibilizados pela Constituição Federal.

\section{REFERÊNCIAS}

BARROSO, Luís Roberto. O direito constitucional e a efetividade de suas normas. $5^{\text {a }}$ ed. Rio de Janeiro: Renovar, $9^{\mathrm{a}}$. Ed. 2009..

BOBBIO, Norberto. A Era dos Direitos. Rio de Janeiro: Campus, 1992.

CAPPELLETTI, Mauro e GARTH, Bryant. Acesso à justiça . 1a. Ed. Reimpressão 2002. Tradução de Ellen Gracie Northfleet. Porto Alegre: Editora Sérgio Antônio Fabris, 1988.

CARVAlHO FILHO, José dos Santos. Ação Civil Pública: Comentários por artigo, 3. Ed. Rio de Janeiro: Lumen Juris, 2001

FERREIRA, Helini Sivini. Os instrumentos jurisdicionais Ambientais na Constituição Brasileira. In Direito Constitucional Ambiental Brasileiro. CANOTILHO, José Joaquim e LEITE, José Rubens Morato, Organizadores. 2ª Ed. São Paulo: Saraiva, 2008. 
FIORILLO, Celso Antonio Pacheco. Curso de Direito Ambiental Brasileiro, 16 ed. São Paulo: Saraiva, 2015.

JELLINEK, George. Teoria general del Estado. Trad. Por Fernando de los Rios. 2 ed. Buenos Aires: Editorial Albatroz, 1974.

KRELL, Andreas. Direitos sociais e o controle judicial no Brasil e na Alemanha. Porto Alegre: Sérgio Antonio Fabris Editor, 2002.

LEITE, José Rubens Morato e AYALA, Patryck de Araújo. Dano Ambiental. Do individual ao coletivo extrapatrimonial. Teoria e Prática. 6. ed. São Paulo: Ed. Revista dos Tribunais, 2014.

MACHADO, Paulo Afonso Leme. Direito Ambiental Brasileiro. 24a Ed. São Paulo, Malheiros: 2016.

MILARÉ, Edis. Ação civil pública completa 20 anos. In RT Informa $\mathrm{n}^{\circ} 37$ maio/junho 2005. Revista dos Tribunais, 2005.

PACHECO, José da Silva. Ações Constitucionais Típicas. $4^{\text {a }}$ Ed. São Paulo: RT, 2002.

SILVA, José Afonso da. Direito Constitucional Ambiental. 39ª Ed. São Paulo: Malheiros, 2016.

SIRVINSKAS, Luís Paulo. Manual de Direito Ambiental, 5a Ed. São Paulo: Saraiva, 2007.

THEODORO, Marcelo Antonio. Direitos Fundamentais e sua Concretização. Curitiba: Juruá, 2002; 